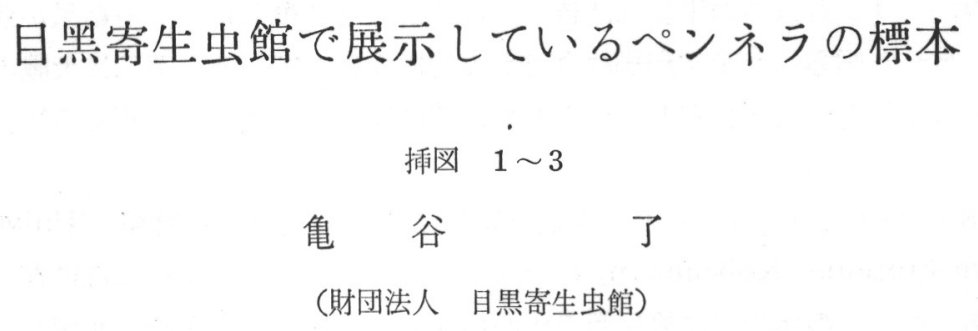

\title{
On two Species of Pennella (Parasitic Copepod) exhibited in the Meguro Parasitological Museum
}

\author{
With 3 Text-figures \\ Ryo KAMEgAYA \\ (Meguro Parasitological Museum, Tokyo)
}

目黒寄生虫館で展示しているペンネラについて簡単に紹介しよう。

Pennella は Crustacea (甲殸類) Copepoda (撓脚目) Lerneaidae (イカリムシ科) に属する種類である。宿主は, 鯨マンボウ, メカヂキ等海産の生物で, その体表に外部寄 生をする。当館では, 須磨水族館吉田啓正氏より寄贈ららけた Pennella orthagorisci WRIGHT, 鯨類研究所より提供をうけた Pennella balaenopterae KOREN \& DANIELSSEN を展示している。いうまでもなく前者はマンボウに寄生し, 後者はクジラ（ナガスクジ ラ）に寄生していたものである。尚参考むでにメカジキのものも紹介する。

\section{Pennella orthagorisci $\mathrm{W}_{\mathrm{RIGHT}}$}

P. orth. について, 少しく調査したので簡単な記載を試みる。 採集地：瀬戸内海淡路島岩屋町沖

採集日：昭和32年 4 月

採集者：吉田啓正氏

宿 主: Orthagoriscus マンボウ，体重 $80 \mathrm{~kg}$ の体表

雌の虫体 2 匹についてのべると, 全体は球状の頭部と細長い頸部, これより太い生殖器 部, それにつづく後腹部と 2 条の産卵管からなっている。全体の長さは $12.3 \mathrm{~cm}$ と $13.0 \mathrm{~cm}$ であった。

頭部は直径約 $5 \mathrm{~mm}$, 大体球状を呈し, 中央に縦軸によって軽い凹部ができて扣り, 二 つにわれているような外観を呈する。との先端約 $1 / 3$ に小突起が密集して, 帽子をかぶっ たよらである。頭部と頸部の接するところから突起が 3 本でている。左右の 2 本は $5 \sim 3$ $\mathrm{mm}$ の長さがあり, 左右同長である。突起の先端は丸味をおびて少し太くなっている。中 央の 1 本は痕跡か $1 \mathrm{~mm}$ 位の小突起にすぎない。両突起は背面が後方にのびていて, 軸と 
の角度は $30^{\circ}$ 位であり, 両突起の間の角度は $130^{\circ}$ である。

頸部は長さ $50 \sim 57 \mathrm{~mm}$ あり, 巾は $2 \mathrm{~mm}$ 位で すらりとして細長い。頸部につづく生殖器部は 44〜 48mm の長さと3.0〜3.5mm の巾を有し, 頸部に較べると強剛にみえる。それには環状の 媰がある。その末端から 2 本の産卵管が伸びて いるが，その長さは150～170mmある。

生殖器部につつくく後腹部は23〜30mmあって, その腹面には軟骨性の繊維束が密生している。 この繊維束は基部では二又にわかれているが, それが $2 \sim 3$ 本に分枝し, 更らに多数の線状体 にわかれ，極めて複雑な形をしている。又中に はあまり分れていない繊維束もある。

色は既にフォルマリンに漬けて長期に保存さ れているから判然しないが, 今日では頭部, 頸 部は淡黄褐色, 生殖器部, 後腹部は濃紫褐色で, むしろ黒色といった方がよいかも知れない。

この Pennella の体表には生殖器部, 後腹部 に美しい Conchoderma virgatum (SPENGLER) スジェボシが $2 \sim 3$ コ着生している。

\section{Pennella balaenopterae Koren} \& DANIELsSEN

本虫は颜類研究所より提供をらけて展示中の もので Balaenoptera musculus シロナガス クジラの体表に寄生していたものという以外に は詳しい記録がない。

頭部はやや球形で長経 $5 \mathrm{~mm}$, 短経 $3 \mathrm{~mm}$, 頸部と頭部との間から 3 本の突起が出ている。 2 本は長くて $10 \mathrm{~mm}, 16 \mathrm{~mm}$ あり，1本は短く て $7 \mathrm{~mm}$ ある。突起の先端はやや丸味を和びて いる。頸部は78mm, 生殖器部は $60 \mathrm{~mm}$, それ につづく産卵管は $150 \mathrm{~mm}$ 前後ある。

その他の形態は Pennella orthagorisci に 非常によくにている。主な相違点は突起の部分 だけといってよい。

参考のために Pennella balanopterae につ

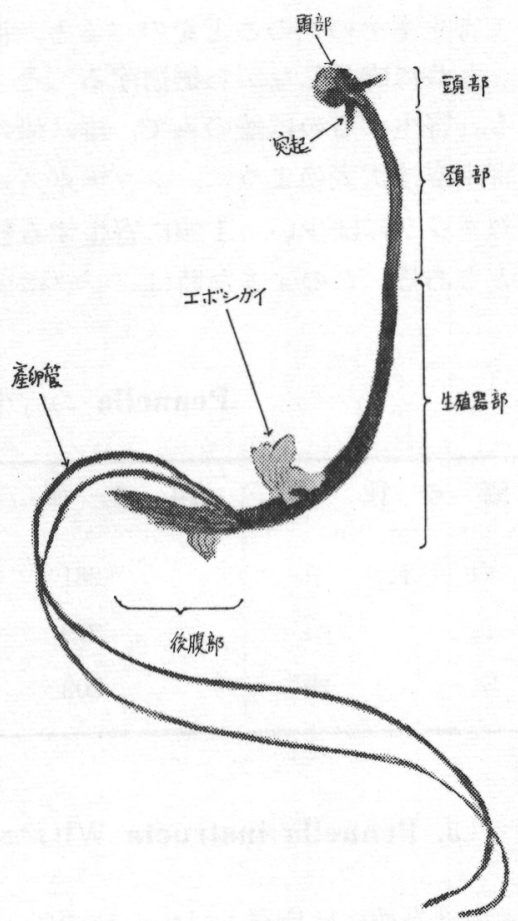

第1図 マソボウのペンネラ Pennella Orthagorisci E. P. WRIGHT

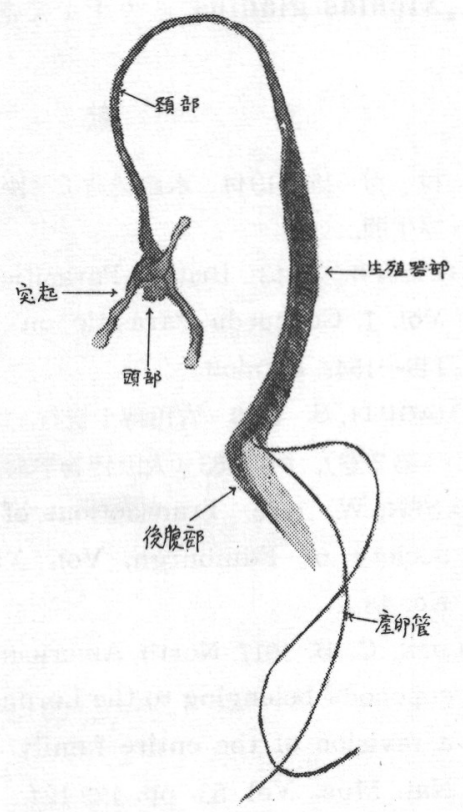

第2図ナガスクジラのペンネラ Pennella balaenopterae KOREN \& DANIELSSEN 
いて奇生率その他のことをのべると, 温暖水域でクジラの頭部, 肩, 背面等に寄生し, ク ジラと共に成長しながら趣游する。とうして南氷洋にくると脱落して痕跡をのこすのみと なる。寄生するのは雌のみで, 雄は雌の体の一部に寄生している。

寄生率は次表のように, シロナガスクジラ, ナガスクジラで1.0，0.7\%であり，他の種 類のクジラには少い。1 頭に寄生する数は $5 \sim 6$ 匹のことが多いが，中には全身にわたる こともある,このような時はクジラは弱る。

Pennella の寄生率（鯨研, 大村秀雄博士調）

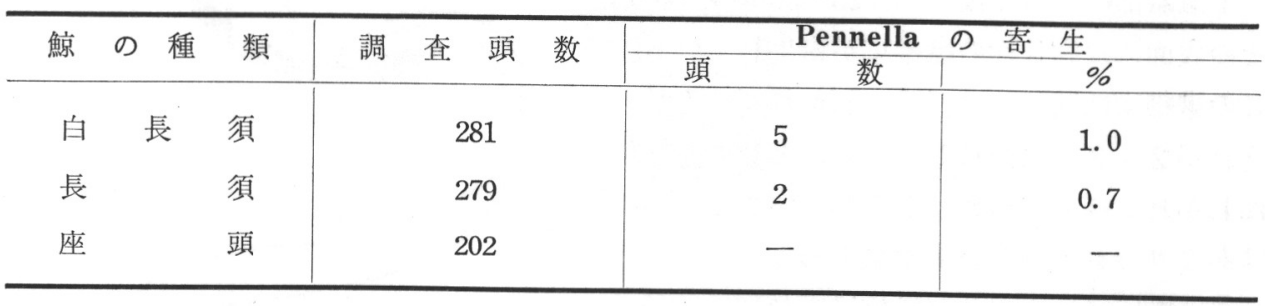

\section{Pennella instructa WILSON, 1917}

本虫は当館には所蔵していないので, 山口左仲 博士の著書から参考までに図を引用しておく。宿 主はXiphias gladius メカヂキである。

\section{文献}

大 村 秀 雄 1944 水産製造工学座, 鯨類, 68, 厚生閣。

Scotт. Th. 1913 British Parasitic Copepoda.

Vol. 1, Copepeda Parasitic on Fishes, pp. 149-154. London.

YAMAGUTI, S. 1939 吉田博士祝賀記念誌, 欧文篇 (第 2 巻), pp. 483 (大阪博物学会)

TURnen, W. 1905 Transactions of the Royal Society of Edinburgh, Vol. XIi, Part 2, No. 18.

Wilson, C. B. 1917 North American Parasitic copepods belonging to the Lernaeidae with a revision of the entire family. Proc. U.S. Nat. Mus., Vol. 53. pp. 122-124.



第3図メカジキのペンネラ, Pennella instructa WILSON (山口左仲原図)

亀谷了・野々部春登・木原 緑・亀谷俊也 1961 Pennella orthagorisci WRGIHT の一例。 目黒寄生虫月報，23，2. 